\title{
HLA Class I and Plasma Viral Load of HIV-1 in Sexually Transmitted and Reproductive Tract Infections among Heterosexual Serodiscordant couples in
}

\section{Nigeria}

Otuonye $\mathrm{NM}^{1^{*}}$, Luo $\mathrm{Ma}^{2}$, Chris Chinweokwu ${ }^{3}$, Aniedobe $\mathrm{MN}^{6}$, Okoye $\mathrm{RN}^{6}$, Enya $\mathrm{VN}^{5}$, Ogbonna $\mathrm{FN}^{6}$, Audu $\mathrm{R}^{7}$, Uwandu $\mathrm{M}^{7}$, Adedeji $\mathrm{A}^{8}$, Ponmak $\mathrm{J}^{7}$, Nduaga $\mathrm{S}^{9}$, Akindele $\mathrm{SK}^{6}$, Liboro $\mathrm{GO}^{7}$, Odewale $\mathrm{EO}^{7}$, Adesesan $\mathrm{AA}^{9}$, Musa $\mathrm{AZ}^{8}$, Ezechi $\mathrm{O}^{4}$, Ojetunde $\mathrm{MM}^{1}$ and Odunukwe $\mathrm{NN}^{4}$

1. Central Research Laboratory, NIMR, Yaba.

2. National Microbiology Laboratory, Winnipeg, Manitoba Canada.

3. Immunology Dept. Nnamdi Azikiwe University, Anambra State Nigeria

4. Clinical Science Department, NIMR, Yaba

5. Public Health Department, NIMR, Yaba

6. Clinical Diagnostic Laboratory, NIMR, Yaba

7. Centre for Human Genomics and Virology, NIMR, Yaba

8. Monitoring and Evaluation Unit, NIMR

9. Centre for TB Research, NIMR, Yaba

*Correspondence: Ngozi Mirabel Otuonye

Central Research Laboratory, Nigerian Institute of Medical Research (NIMR)

PMB 2013

Yaba, Lagos, Nigeria

Tel: +2348033810466

Email address: mnotuonye@gmail.com 


\begin{abstract}
Background: This study investigated HLA Class I in Long Term Non-progressors (LTNPs) and plasma viral load in Sexually Transmitted and Reproductive Tract Infections (STIs/RTIs) associated with Heterosexual HIV-1 transmission among serodiscordant couples in Nigeria.

Methods: A total of 271 serodiscordant and concordant couples (HIV positive and negative) were enrolled, blood samples were collected from the subjects by venipuncture. HLA class I (with specific primers), plasma viral load, CD4+ analysis was done. Endocervical/urethral swabs and early morning urine samples were collected by standard microbiological methods. These were screened by microscopy, culture, antibiogram, and biochemical tests with a view to identify aetiologic agents of co-infections with HIV.
\end{abstract}

Results: The Participants age ranged from $\geq 21-<50$ years. The index whose plasma viral loads were 10,001-100,000 copies/ml had STIs/RTIs 32(60.9\% p=0.059). Staphylococcus aureus and Escherichia coli $(22.1 \%)$ were isolated from the index (HIV positive subject) while $14.5 \%$ of Staphylococcus aureus and $27.2 \%$ of $E$ coli were isolated from their partners (HIV negative subject). Staphylococcus aureus and $E$ coli are normal flora but because the patients are Immunocompromised as a result of positivity to HIV, Staphylococcus aureus and E. coli in this context becomes opportunistic thereby, causing genital tract infections. Staphylococcus from the index showed more sensitivity to Amoxicillin/clavulanate $(95.4 \% / 90.4 \%)$ compared to the partners $(55.1 \% / 73.5 \%)$ and more resistant to Ceftazidime $(81.4 \%)$ compared to the partners $(68.9 \%)$. LTNPs were 28(8.51\%) among the index. HLA-B alleles: B*5701 (9.2\%), B*5703 $(4.6 \%)$ and $\mathrm{B} * 5801(12.5 \%)$ were identified for viral control at late stage of HIV infection while $\mathrm{A}^{* 1}$ (4.6\%), and $\mathrm{C}^{*} 0701(29.1 \%)$ were protective alleles observed. HLA-B*0702 (33.3\%), $B * 4201 / A * 2301(4.6 \%)$ respectively were susceptible alleles associated with seroconversion among LTNPs. 
medRxiv preprint doi: https://doi.org/10.1101/2021.08.23.21262283; this version posted August 25, 2021. The copyright holder for this preprint (which was not certified by peer review) is the author/funder, who has granted medRxiv a license to display the preprint in perpetuity.

It is made available under a CC-BY-NC-ND 4.0 International license.

Conclusion: The microorganisms isolated from the index were associated with high viral loads and are independent makers to HIV-1 transmission among serodiscordant couples. Individuals associated with HLA class I alleles identified among LTNPs were those significantly associated with resistance and susceptible to HIV-1 infections.

\section{Key words:}

HLA class I, HIV-1, STIs/RTIs, pLV, Heterosexual serodiscordant couples and Nigeria. 


\section{INTRODUCTION}

About 36.7 million people globally are currently living with HIV infection ${ }^{1,2 .}$ Nigeria has the 2 nd largest HIV epidemic in the world with prevalence of $3.1 \%$ and has the highest new infection rates in sub Saharan Africa ${ }^{3}$ HIV is a public health problem; over $65 \%$ of the world's HIV infection is found in sub Saharan Africa with heterosexual exposure as the primary mode of HIV transmission ${ }^{4}$ Approximately 80 percent of HIV infections in Nigeria are as a result of heterosexual sex ${ }^{4}$. However, many couples do not know their HIV status and so, this has given room to most heterosexual HIV-1 transmission among serodiscordant couples ${ }^{3,4}$. Again, an estimated 70\% HIV -1 transmission occur between married partners, making cohabiting African couples the largest HIV risk group ${ }^{5,6}$. Factors contributing to this includes: Lack of knowledge about sexual health, non to inconsistent condom use, untreated ulcerative and non-ulcerative sexually transmitted diseases, reproductive tract infections, non-disclosure of partner HIV status, multiple sexual partners and vaginal washing ${ }^{7,8,3}$. However, gender inequality among women has been identified as a strong factor to HIV epidemic in African women ${ }^{8}$.

Vaginal infections which are caused by bacterial vaginosis (BV), bacterial pathogens (BP) and yeast infections (YI) are common among HIV-infected men and women especially during the reproductive age. This may be a marker for increased transmissibility to sexual partners, infants at delivery, significant morbidity, underscoring their importance from a public health perspective. Severe co- infections have been reported in serodiscordant couples. In a recent study, 564 patients presented to the Nigerian Institute of Medical Research (NIMR) HIV clinic with symptoms of lower waist pain, painful urination, vaginal/ urethral itching, discharge, certain foul-smelling fluid from the vagina and/or a balloon-like feeling from the vagina. Results 
medRxiv preprint doi: https://doi.org/10.1101/2021.08.23.21262283; this version posted August 25, 2021. The copyright holder for this preprint (which was not certified by peer review) is the author/funder, who has granted medRxiv a license to display the preprint in perpetuity.

It is made available under a CC-BY-NC-ND 4.0 International license .

presented showed fifty-five bacterial isolates co-infected with Candida species, while 5 Trichomonas vaginalis co-infected with candida species, 23 bacterial vaginosis (BV) co-infected with other bacterial pathogens ${ }^{8}$. About 10 patients had triple infection of $\mathrm{BV}$, yeast and bacterial pathogens. Co-existence of reproductive tract infections (RTIs) was associated with increased HIV transmission through heterosexual contact $(\mathrm{p}<0.002)^{8}$. Though, traditionally, reproductive tract infections have been viewed as a lesser public health importance. In another study on lower genital tract infections in HIV-seropositive women in India, the laboratory findings showed high prevalence of BV (30\%), mixed infection (30\%), and candidiasis (10\%) among HIV-seropositive women $(P<0.001)^{9}$.

Another study in India identified sexually transmitted infections in 57\% of HIV positive women compared to $34 \%$ of HIV negative women $(\mathrm{p}=0.0037)$. Vaginal candidiasis was the most common infection followed by Trichomonas vaginalis. Human papilloma virus infection was seen in nine HIV positive women and none was seen in HIV negative women ${ }^{10}$. Symptomatic vaginal yeast infections are increased in HIV-infected women with low CD4 cell count if they are not on antifungal prophylaxis. Significantly, vaginal infections may cause significant morbidity, especially among HIV-infected women, and may contribute to increased risk of HIV transmission among sexual partners. Serodiscordant couples involved in oral sexual practices can be of high risk in HIV-1 transmission if there are open sores in the mouth. The sexual practices with the highest risks are those that cause mucosal trauma, during intercourse while analreceptive intercourse poses the highest risk. Mucous membrane inflammation facilitates HIV transmission. Sexually Transmitted Diseases, such as gonorrhea, chlamydial infection, trichomoniasis, cause ulceration. Chancroid, herpes, and syphilis, increase HIV risk acquisition 
in several folds. In heterosexuals, the estimated risk per coital act is about $1 / 1000^{11}$. However, the risk is increased in early and advanced stages of HIV infection when HIV concentrations in plasma and genital fluids are higher, in younger people with ulcerative genital diseases ${ }^{12}$. The risk of HIV acquisition in a single sexual exposure is estimated to be very low ${ }^{13}$. However, the key factor in determining the viral load burden is the exposing dose of the virus from an Index to the partner ${ }^{14}$. A study conducted in Uganda on heterosexual HIV serodiscordant couples showed a direct relationship between the risk of HIV acquisition and donor plasma viral load (pVL) ${ }^{15}$. No HIV transmissions were observed when the pVL was below a critical threshold of 1500 copies HIV RNA/ml ${ }^{15}$.

Human Leucocyte Antigen (HLA) play a crucial role in HIV diseases progression or seroconversion $^{16,17}$. However, the role HLA play in HIV-1 transmission in serodiscordant couples in Nigeria is unknown. HLA is the human version of the Major Histocompatibility Complex in $\operatorname{man}^{18 .}$ HLAs are complex, genetically inherited proteins present on the surface of human cells, located at the short arm of chromosome $6(6 \mathrm{p} 21)$ and spans approximately 4.0 kilobases of DNA. It is known to be the most polymorphic genetic system in humans ${ }^{16}$. HLA is made up of class I (HLA-A, -B and -C) and class II (DP, DQ, DR, DM, DP and DP) ${ }^{17}$. Several studies particularly on Western populations have demonstrated their implications in many autoimmune and infectious diseases including HIV ${ }^{17}$. The biological role of the HLA class I and II molecules are to present processed peptide antigens (HIV, bacteria and other viruses) to CD8+ cytotoxic $\mathrm{T}$ lymphocytes and CD4+ respectively for immune recognition and stimulation with the aim of destroying the pathogen from which the antigenic peptide came from ${ }^{18}$. Studies have shown that, the genetic make-up of a person's HLA affects the rate of HIV disease progression ${ }^{16}$. 
Long Term Non-progressors are a minor percentage of individuals (5-10\%) who remains asymptomatic of HIV infection ${ }^{19}$. These subset of HIV-1 infected individuals can control HIV replication which is linked to the expression of certain HLA class I alleles particularly B*5701, $\mathrm{B} * 5703, \mathrm{~B} * 27$ and $\mathrm{B} * 5801^{20}$. LTNPs' immunologic basis is also linked to cytotoxic lymphocyte functions (CD8+). Their CD4 ${ }^{+}$T-cell counts is $>500 \square$ cells $\square \mathrm{mm}^{-3}$ for $>10$ or more years with viral loads under 1,000 copies RNA/ml blood ${ }^{21}$. Many of these patients have been HIV positive for 30 years without ARV medications ${ }^{21}$. Some authors suggested that some LTNPs are infected with a weakened or inactive form of HIV while some believe that many LTNP patients carry a fully virulent form of the virus ${ }^{19}$. Again, some HLA alleles have been documented by another study to determine the rate of HIV-1 seroconversion and disease progression in 1000 Pumwani sex workers in Kenya ${ }^{22}$. From their analysis, they reported that women with HLA- A*01, $\mathrm{C}^{*} 0602$ and $\mathrm{C}^{*} 0701$ are less likely to seroconvert and conversely women who have A*2301 (P $=0.004), \mathrm{B} * 070201(P=0.003)$ and $\mathrm{B} * 4201(P=0.025)$ are independently associated with rapid seroconversion. Therefore, it becomes necessary to know if these LTNPs also harbour some of these HLA alleles previously documented to protect, restrict or lead to HIV-1 disease progression.

In this study, we therefore;

1. Investigated the role of plasma viral load (HIV-1 RNA) in association with sexually transmitted infections and reproductive tract infections (STIs/RTIs) and behavioural cofactors in HIV-1 transmission among serodiscordant couples.

2. Identified the antibiotic susceptibility and resistance patterns of the STIs/RTIs isolates predominant in serodiscordant couples. 
3. Documented the profile of HLA class I alleles in Long Term Non-Progressors in association of plasma viral load in transmitting HIV -1 from index to their partners

4. Matched specific HLA alleles in Long Term Non- Progressors associated with protective, resistance and susceptible to seroconversion to HIV diseases with other alleles identified in previous studies. 


\section{Subjects, Materials and Methods}

\section{Recruitment of study population}

The study population comprised of: Serodiscordant couples (Index and Partner). The positive partner may or may not be on antiretroviral drugs (ART). Concordant couples were also recruited: in this case, the couple can be concordant HIV positive and or concordant HIV negative. These couples were registered with the Nigerian Institute of Medical Research (NIMR) HIV clinic Yaba, Lagos and Nnamdi Azikiwe University Teaching Hospital Nnewi Anambra State (NAUTH) HIV clinics. Other clients were recruited from NIMR HCT Unit (HIV Counseling and Testing Unit). HIV negative couples were recruited among NIMR Workers (NIMRWC) and Divine Grace Church Couples (DGCC) for control measures. Only couples who gave informed consent and were recruited.

\section{Study design}

Case-control study of the people living with HIV/AIDS and their HIV negative partners (serodiscordant couples), concordant HIV positive couples and concordant HIV negative couples (control) with previous or current history of cervicitis, pelvic inflammatory disease (PID), painful urination, itching and foul-smelling vagina, were enrolled for the study.

\section{Focus group discussion and Consent documentation}

Participants were counseled and told to inform their partners about the research in other to facilitate their consent. The partners of all index were screened for HIV. Those who subsequently turned out to be HIV positive were referred to NIMR and NAUTH HIV Counseling and Testing unit for confirmation of their sero-positive status, and finally referred to the HIV 
clinic for management. Couples recruited from amongst NIMR workers (NIMRWC) and Divine Grace Church Couples (DGCC) were all screened for HIV to confirm their sero-negative status. Informed consent was obtained from all the participants. This was obtained during focus group discussions conducted in an appropriate meeting room.

\section{Study Sites}

Samples were collected and processed in two government-owned health institutions namely:

Nigerian Institute of Medical Research Yaba, Lagos State and Nnamdi Azikiwe University Teaching Hospital Nnewi, Anambra State. HLA studies were carried out at National Microbiology Laboratory Winnipeg, Manitoba Canada.

Sample size Calculation

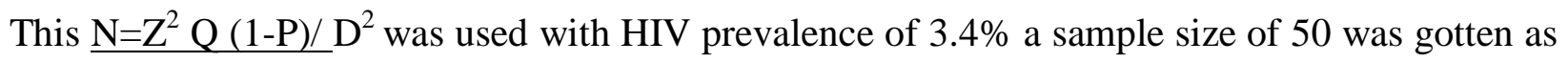
follows: $\mathrm{N}=0.034 \times 3.8416$ X0.966/ $0.0025=50$.

Following the HIV prevalence rate used (3.4\%), the sample size to be used for the study is 50 but considering how little the sample size was, I had to make it a case control study so that a larger population can be recruited in the study. The initial calculation in the first paper sent was wrong and that was why it was looking like an understudy.

\section{Inclusion and Exclusion Criteria}

The participants included in this study were: (1) Couples that have discordant HIV test result. (2) Couples that have concordant HIV results (3) Couples who have co-habited for at least 3 months and or may have more than one partner. (4) The women are aged between 20-60 and the men 20- 
medRxiv preprint doi: https://doi.org/10.1101/2021.08.23.21262283; this version posted August 25, 2021. The copyright holder for this preprint (which was not certified by peer review) is the author/funder, who has granted medRxiv a license to display the preprint in perpetuity.

It is made available under a CC-BY-NC-ND 4.0 International license .

65 years. (5) The HIV positive partners can be or not be on ARV. (6) Willingness to participate and given informed consent.

Also excluded were (1) Those over/or under the required age group (2). Those, who have not cohabited for three months (3) Those who are not willing to participate and give informed consent.

Ethical Approval: Approval was obtained from NIMR IRB (IRB/12/176) and NAUTH Ethical Committee (CS/66/7/79).

\section{Administration of Structured Questionnaire using In-depth Interview (IDI) Procedures and face to face interviews}

Structured questionnaires were administered to a total of 224 consenting sero-discordant couples, 26 concordant HIV positive and 21 concordant HIV negative couples. Information on sociodemographic characteristics, knowledge of partners' HIV status, knowledge of STIs, laboratory tests and treatment status, sexual behaviours and practices, were required for the completion of the questionnaire. This procedure was done during couples counseling and testing

\section{Couples Voluntary Counseling and Testing (CVCT) for HIV Prevention}

In this study $99.8 \%$ of the couples accepted to be counseled together. The $0.2 \%$ that were counseled separately but later brought together was because their wives suspected their husbands of infidelity and gave room for their husbands to say the truth. However, counseling both partners in a serodiscordant relationship at the same time (couples-based counseling) has been proved to be more effective in reducing risk behaviours compared to counseling the partners individually $^{25}$. In this study, couples-based counseling created a supportive space where partners came to an agreement on how to reduce their risk of HIV transmission and develop ways to support each other in using HIV prevention strategies continuously and correctly. Couples were 
medRxiv preprint doi: https://doi.org/10.1101/2021.08.23.21262283; this version posted August 25, 2021. The copyright holder for this preprint (which was not certified by peer review) is the author/funder, who has granted medRxiv a license to display the preprint in perpetuity.

It is made available under a CC-BY-NC-ND 4.0 International license .

supported to discuss potentially sensitive issues relevant to HIV prevention, such as sexual intimacy, interpersonal dynamics and whether there are sexual partners outside of the relationship. Through counseling, heterosexual serodiscordant couples explored if the plans to have children may influence the acceptance of HIV prevention strategies.

\section{Laboratory investigations}

\section{Sample collection methods}

A total of 472 blood samples, 123 endocervical swabs, 11 urethral swabs, 109 urine samples were collected from 236 couples from Nigerian Institute of Medical Research. Seventy (70) blood samples, 28 urine samples and 3 endocervical swabs were also collected from 35 couples from Nnamdi Azikiwe University Teaching Hospital Nnewi Anambra State. The participants that were swabbed and brought early morning urine samples presented with: vaginal discharge, pelvic inflammatory diseases (PID) itching, painful urination and foul smell from the vagina. The swabs and the urine samples were cultured using standard microbiological methods.

\section{Isolation and Identification of microorganisms associated with Sexually Transmitted and}

\section{Reproductive Tract Infections}

\section{Culture}

Endocervical/urethral swabs were cultured on chocolate and blood agar under $\left(\mathrm{CO}_{2}\right)$, and Sabouraud Dextrose agar plates and placed at $37{ }^{0} \mathrm{C}$ for 24 hours. Additionally, urine samples were cultured on MacConkey, CLED and blood agar plates, placed at $37^{\circ} \mathrm{C}$ for 24 hours, using standard microbiological techniques. Characterization and identification were done on the 
medRxiv preprint doi: https://doi.org/10.1101/2021.08.23.21262283; this version posted August 25, 2021. The copyright holder for this preprint (which was not certified by peer review) is the author/funder, who has granted medRxiv a license to display the preprint in perpetuity.

It is made available under a CC-BY-NC-ND 4.0 International license.

microbial isolates using standard microbiological techniques such as cultural, morphological and biochemical characteristics accordingly ${ }^{26}$. 


\section{Wet Preparation}

This was done on endocervical swabs and urine samples to determine the presence of clue and yeast cells and T. vaginalis using standard microbiological methods ${ }^{25}$.

\section{Gardnerella vaginalis detection (Bacterial Vaginosis $\{\mathrm{BV}\}$ )}

$\mathrm{BV}$ diagnosis was done using the presence of the three Amstel criteria which include vaginal $\mathrm{pH}$, greater than 4.5, positive whiff test, milky discharge, and the presence of clue cells on microscopic examination of vaginal fluid ${ }^{27}$.

\section{Antibiotic Susceptibility Testing}

The disk-diffusion agar method tests the effectiveness of antibiotics on a specific microorganism. The inoculum for each bacterial isolate was prepared directly from corresponding overnight culture after 24 hours incubation at $37^{\circ} \mathrm{C}$ were prepared directly from overnight cultures adjusted to 0.5 McFarland standard. Whatman Antibiotic Assay Single Discs (9mm) already impregnated with a known volume of appropriate concentration of antimicrobial, representing Gram positive and negative antibiotics compromising of: Ofloxacin $(5 \mu \mathrm{g})$, Gentamycin $(10 \mu \mathrm{g})$, Amoxicillin/Clavulanate $(10 \mu \mathrm{g})$, Amoxicillin $(10 \mu \mathrm{g})$, Ciprofloxacin $(5 \mu \mathrm{g})$, Nitrofurantoin $(100 \mu \mathrm{g})$, Erythromycin $(10 \mu \mathrm{g})$, Cefotaxime $(30 \mu \mathrm{g})$, were placed aseptically on the inoculated plates. The plates were incubated for 24 hours at $37^{0} \mathrm{C}$. Clear Zones of Inhibition was measured in millimetres using a ruler on the underside of the plate. Zone measurements (+/$2 \mathrm{~mm}$ ) with $96 \%$ of the tests was accepted as the right zone of inhibition according to the KirbyBauer procedure ${ }^{28}$. Isolates showing resistance to three or more categories of antibiotics were considered as multidrug resistance bacteria. 
medRxiv preprint doi: https://doi.org/10.1101/2021.08.23.21262283; this version posted August 25, 2021. The copyright holder for this preprint (which was not certified by peer review) is the author/funder, who has granted medRxiv a license to display the preprint in perpetuity.

It is made available under a CC-BY-NC-ND 4.0 International license
. 


\section{HIV-1 RNA Assay (plasma viral load)}

Determination of the Amplicor HIV-1 MONITOR Test version 1.5 is an in vitro nucleic acid amplification test for the quantitation of RNA copies/ml of plasma of HIV-1 RNA in human plasma. Five stages were involved: Pre-PCR reagent, Pre-PCR standard specimen preparations, amplification, detection, calculation and interpretation of results. The HIV-1 RNA copies/ml of plasma were calculated as copies/PCR x $40=\mathrm{HIV}-1 \mathrm{RNA}$ copies $/ \mathrm{mL}^{29}$.

\section{CD4 Count}

Twenty $(20 \mu 1)$ microlitre of whole blood, $20 \mu 1$ of CD4 mAb PE was added to Partec test tubes and incubated for 15 mins in the dark. Subsequently, $800 \mu l$ of no lyse buffer was added and vortexed gently. Total counting of CD4+ was done by Partec devise Cyflow which is a desktop flow cytometer. Result was displayed on the computer screen and calculated in cells $/ \mathrm{mm}^{3}$. Normal range in HIV negative individual is $400-1600$ cells $/ \mathrm{mm} 3$ as described ${ }^{30}$.

\section{White cell Harvesting and DNA Extraction}

White cell pellet was harvested from buffy coat on peripheral blood cells with the use of Aceshocking solution. The white cells pellet was used for Qiagen DNA extraction. DNA was extracted from white cell pellet with genomic DNAQIAGEN kit as described ${ }^{31}$. The DNA filtrate was placed in the cryovial and stored frozen at $-800 \mathrm{C}$ or $-200 \mathrm{C}$ for further analysis.

\section{Polymerase Chain Reaction (PCR) for DNA Amplification}

PCR reactions were performed on 96-well plates. Each reaction was composed of $20 \mu 1$ of $\mathrm{ddH}_{2} \mathrm{O}, 5 \mu \mathrm{l}$ of gDNA, and $25 \mu \mathrm{l}$ of master mix. The master mix contained $22.75 \mu \mathrm{l}$ of $2 \mathrm{X}$ mix 
medRxiv preprint doi: https://doi.org/10.1101/2021.08.23.21262283; this version posted August 25, 2021. The copyright holder for this preprint (which was not certified by peer review) is the author/funder, who has granted medRxiv a license to display the preprint in perpetuity.

It is made available under a CC-BY-NC-ND 4.0 International license .

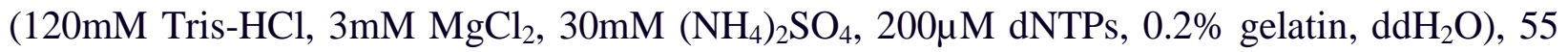

pmol of both the forward and reverse primer and $13.75 \mu \mathrm{l}$ of Taq polymerase. For HLA-C typing, primers were set to detect polymorphisms in exons 2 and 3 of the class 1 genes. The structural sequence of the primers used for HLA-A, -B and -C were as follows: APCRF represents HLA-A Forward Primers and APCRF: HLA-A Forward Primers. BPCRR represents HLA-B Reverse Primers and BPCRF: HLA-B Forward Primers. While CPCRR represents HLAC Reverse Primers and CPCRF: HLA-C Forward Primers as shown below ${ }^{32}$.

$\begin{array}{lc}\text { HLA gene Primer name } & \text { Nucleotide Sequence 5' - 3'o } \\ \text { HLA-A PCR Forward } & \text { GAAACSGCCTCTGYGGGGAGAAGCAA } \\ \text { HLA-A PCR Reverse } & \text { TGTTGGTCCCAATTGTCTCCCCTC } \\ \text { HLA-B PCR Forward } & \text { GGGAGGAGCGAGGGGACCGCAG } \\ \text { HLA-B PCR Reverse } & \text { GGAGGCCATCCCCGGCGACCTAT } \\ \text { HLA-C PCR Forward } & \text { ARCGAGGKGCCCKCCCGGCGA } \\ \text { HLA-C PCR Reverse } & \text { CGTGGRAGGCCATSCCGGGAGAT }\end{array}$

\section{Agarose gel Electrophoresis}

This was used to confirm that PCR was successful in amplifying the desired HLA gene. Each sample as was run in a $1 \%(\mathrm{w} / \mathrm{v})$ agarose gel in $1 \mathrm{X}$ TBE buffer and stained with $0.003 \%$ $10 \mathrm{mg} / \mathrm{ml}$ Ethidium Bromide. A $1 \mathrm{~kb}$ ladder was added to the first well of every row. Once the DNA had migrated to a sufficient distance down the gel, they were removed from the tank and illuminated using a BioRad ${ }^{\mathrm{TM}}$ UV Transilluminator 2000. The results were viewed with the BioRad $^{\mathrm{TM}}$ Quantity One® software accordingly ${ }^{33}$

\section{Purification of PCR Product}

Following sequencing PCR, the PCR product was precipitated using $21 \mu \mathrm{l}$ of a mixture containing $5 \mathrm{ml}$ of $95 \%$ ethanol and $250 \mu \mathrm{l}$ of sodium acetate. To remove any buffers, salts and 
reagents. Finally, the contents of each well were transferred to MicroAMPTM plates and put in the Applied Biosystems ${ }^{\mathrm{TM}}$ 3130xl Genetic Analyzer for electrophoresis according to Agencourt ${ }^{\circledR}$ AMPure Protocol ${ }^{34}$.

\section{Sequencing HLA PCR}

This protocol was done after the PCR products have been purified. Sequencing HLA is usually focused on the most polymorphic exons 2 and 3 which encode the antigen recognition site as described by Sanger ${ }^{35}$. To genotype HLA class I alleles, exons 2 and 3 were sequenced ${ }^{36}$. Each sequencing PCR reaction contained $4 \mu \mathrm{l}$ of purified PCR product, $1.5 \mu 1$ primer at $3.2 \mu \mathrm{M}$ and $2 \mu \mathrm{l}$ of Applied Biosystems ${ }^{\mathrm{TM}}$. BigDye ${ }^{\circledR}$ Terminator V1.1 or V 3.1. Big Dye V 1.1 was used for HLA-B and -C and Big Dye V 3.1 for HLA-A. The Forward and Reverse Primers used for each HLA gene are shown on the table below:

\begin{tabular}{|c|l|c|c|}
\hline Gene & \multicolumn{1}{|c|}{ HLA Forward and Reverse Sequencing Primers } & BigDye 1.1 & $\begin{array}{c}\text { BigDye } \\
3.1\end{array}$ \\
\hline HLA-A & ASEQ5Forward: GGTTTCATTTTCAGTTTAGGCCA & $\mathrm{X}$ & $\sqrt{ }$ \\
\hline HLA-A & ASEQ3Reverse: ATCTCGGACCCGGAGACTGTG & $\mathrm{X}$ & $\sqrt{ }$ \\
\hline HLA-B & BSEQ5Forward: GGGGACKGGGCTGA & $\sqrt{ }$ & $\mathrm{X}$ \\
\hline HLA-B & BSEQ3Reverse: GGATGGGGAGTCGTGACCTG & $\sqrt{ }$ & $\mathrm{X}$ \\
\hline HLA-C & CSEQ5Forward: GGGGACBGGGCTGAC. & $\sqrt{ }$ & $\mathrm{X}$ \\
\hline HLA-C & CSEQ3Reverse: GCCGTCCGTGGGGGATG & $\sqrt{ }$ & $\mathrm{X}$ \\
\hline
\end{tabular}

For sequencing-PCR, each primer (forward or reverse) was in separate reactions

\section{Ethanol Precipitation}

Following sequencing PCR, the PCR product was precipitated using $21 \mu \mathrm{l}$ of a mixture containing $5 \mathrm{ml}$ of $95 \%$ ethanol and $250 \mu \mathrm{l}$ of sodium acetate. This process removed any buffers, salts and reagents in the PCR product. Finally, the contents of each well were transferred to 
MicroAMPTM plates and put in the Applied Biosystems $^{\mathrm{TM}}$ 3130xl Genetic Analyzer for electrophoresis.

\section{Biosystems $^{\mathrm{TM}}$ 3130xl Genetic Electropherogram}

Each respondent's sequenced PCR products were loaded in the Biosystems for electrophoresis and data analysis. Data analysis software processed the raw data in the *ab1 file, using algorithms which applies the Multicomponent analysis that separates the four different fluorescent dye signals into distinct spectral components by mathematically filtering fluorescence signal from dyes with emission spectra overlap Basecalling. The selected Basecaller processes the fluorescent signals then assigns a base to each peak (A, C, G, T, or N). Analyzed sample data was displayed as an electropherogram, a sequence of peaks in four colors. Each color represents the base called for the peak ${ }^{37}$

\section{CondonExpress TM}

CodonExpress is a genotyping software based on a Taxonomy-based Sequence Analysis (TBSA) to resolve HLA Heterozygous and homozygous combinations. CodonExpress was used to type the Sequence-Based HLA class 1 genes according to CodonExpress TM, as described by the University of Manitoba, Canada instruction manual ${ }^{38}$.

\section{Sequencher V5 for Data Integrity}

Data Integrity was done by using DNA Sequencher V5 Software. This was done to ensure that all data generated in this study are correct and to rule out all unresolved HLA typing ambiguities as previously reported ${ }^{39}$.

\section{Statistical Analysis}


medRxiv preprint doi: https://doi.org/10.1101/2021.08.23.21262283; this version posted August 25, 2021. The copyright holder for this preprint (which was not certified by peer review) is the author/funder, who has granted medRxiv a license to display the preprint in perpetuity. It is made available under a CC-BY-NC-ND 4.0 International license.

Data generated was entered into IBM SPSS statistics version 20. Cross-sectional analysis using Chi Square was used to identify association between genetic and non-genetic factors. Confidence interval was set at $95 \%$ with level of significance set at $p$ value less than $0.05(P<0.05)^{40}$. 


\section{Results}

\section{The sociodemographic characteristics}

The sociodemographic characteristics of the 271 (542) study participants by site of recruitment are shown on table 1 . Their ages ranged from 20 to 60 years with median age of 38 years. Sixteen couples $16(3.0 \%)$ out of 271 couples were engaged to be married but have been cohabiting and are serodiscordant. The ethnicity showed that $54.9 \%$ were Igbos, $20.9 \%$ Yoruba, 9.3\% Hausa and $14.9 \%$ were of other ethnic extractions. HIV status showed $224(82.7 \%)$ serodiscordant, 26(9.6\%) concordant HIV positive and 21(7.7\%) concordant HIV negative couples as shown on table 1.

\section{The impact in HIV-1 RNA burden (plasma viral load (pVL) and other Biological and behavioural Risk factors}

The impact in HIV-1 RNA burden (plasma viral load) on other risk factors on heterosexual HIV1 transmission is shown on table 2 . The heterosexual index $(P=0.057)$ whose pVL was 10,001 to 100,000 had higher number of sexually transmitted and reproductive tract infections and showed statistical significance to sexually transmitted infections (STIs) and Reproductive Tract Infection (RTIs) $(P=0.059)$.

\section{Microorganisms isolated from people living with HIV (Index) and HIV negative (partners)}

Most organisms isolated occurred as mixed infections in the population of HIV negative individuals which was shown on table $3 \mathrm{a}$. A total number of 55 microorganisms were isolated and out of which, Candida spp. 17(30.9\%) was the most prevalent followed by Escherichia coli 15(27.2\%) and Proteus mirabilis. $2(3.6 \%)$ being the least. Escherichia coli (11) and Candida albicans (11) mostly co-infected followed by Staphylococcus aureus (6) and the least is 
medRxiv preprint doi: https://doi.org/10.1101/2021.08.23.21262283; this version posted August 25, 2021. The copyright holder for this preprint (which was not certified by peer review) is the author/funder, who has granted medRxiv a license to display the preprint in perpetuity.

It is made available under a CC-BY-NC-ND 4.0 International license .

Streptococcus spp. (1). Escherichia. coli and Candida spp. co-infected with each other 5 and 7 times respectively. This is shown on table $3 a$.

Table $3 \mathrm{~b}$ highlighted the microorganisms isolated and the occurrence of mixed infections in HIV positive individuals. A total number of 208 microorganisms were isolated and Candida albicans $56(26.9 \%)$ was the most prevalent followed by Staphylococcus aureus and Escherichia. coli 46 (22.1\%) respectively while Pseudomonas aeruginosa had the least frequency $1(0.4 \%)$. Trichomonas vaginalis: (1.4\%) were seen in HIV positive females. Candida spp. co-infected mostly with Klebsiella spp. (6) followed by Staphylococcus aureus, Escherichia coli and Streptococcus spp. (3) respectively. Gardnerella vaginalis co-infected with Staphylococcus aureus (4), followed by Streptococcus spp. and Klebsiella spp. (2) respectively.

\section{Antimicrobial Susceptibility Patterns of the Bacterial Isolates}

On assessment of the antimicrobial sensitivity patterns of the bacterial isolates of reproductive tract infections in HIV positive and negative individuals, the following were observed: Staphylococcus aureus isolated from HIV positive individuals showed more sensitivity to Amoxicillin/clavulanate $(95.4 \%)$ followed by gentamycin $(90.4 \%)$ compared to HIV negative individuals (55.1\%/34.4\%). Escherichia coli isolated from HIV positive individuals showed more sensitivity to Nitrofurantoin followed by Gentamycin and Ofloxacin (95.4\%/98.5\%/98.0\%) compared to HIV negative individuals $(66.1 \% / 73.5 \%$ /33.0\%). Klebsiella spp. isolated from HIV positive individuals showed more sensitivity to Ofloxacin and Nitrofurantoin (87.7\%) respectively compared to HIV negative individuals $(27.7 \% / 0.0 \%)$. This is shown on table $4 \mathrm{a}$. 
medRxiv preprint doi: https://doi.org/10.1101/2021.08.23.21262283; this version posted August 25, 2021. The copyright holder for this preprint (which was not certified by peer review) is the author/funder, who has granted medRxiv a license to display the preprint in perpetuity.

It is made available under a CC-BY-NC-ND 4.0 International license .

On assessment of the antimicrobial resistant patterns of the bacterial isolates of reproductive tract infections in HIV positive and negative individuals, the following were observed: Staphylococcus aureus isolated from HIV positive individuals showed more resistance to Ceftazidime and Gentamycin (81.4\%/ $72.3 \%)$ compared to HIV negative individuals (68.9\%/6.8\%). Escherichia coli isolated from in HIV positive individuals showed more resistance to Tetracycline and Ofloxacin $(85.9 \% / 76.9 \%)$ compared to HIV negative individuals (11.0\%/33.0\%). Proteus spp. isolated from HIV negative individuals showed more resistance to Gentamycin, Amoxil, Amoxicillin/clavulanate and Ceftazidime (83.3\%) respectively compared HIV positive individuals $(0.0 \% / 48.0 \% / 9.6 \%$ and $0.0 \%)$. This is also shown on table $4 \mathrm{~b}$.

\section{Long Term Non-progressors (LTNPs)}

The display of the length of time the non-progressors have not been on ARV is shown on figure 1. The longest period any of them have lived without drugs is $>7$ years (12 HIV positive individuals) and the shortest is $0-12$ months (57 HIV positive individuals). Table 5 also shows common documented HLA- A, -B and -C alleles identified among LTNPs of Nigerian origin. 
medRxiv preprint doi: https://doi.org/10.1101/2021.08.23.21262283; this version posted August 25, 2021. The copyright holder for this preprint (which was not certified by peer review) is the author/funder, who has granted medRxiv a license to display the preprint in perpetuity.

It is made available under a CC-BY-NC-ND 4.0 International license .

\section{Discussion}

HIV infected subjects acquire new sexually transmitted diseases and reproductive tract infections (STDs/RTIs) at a rate equal to or greater than the HIV negative subjects. This is because these group of people are immunocompromised and are involved in other risky sexual practices such as: failure to use condom during sexual activities, anal or oral sex and some of the patients are involved in poor Antiretroviral drugs (ARV) adherence which may result in HIV mutation and leads to increase in opportunistic infections. Sixty-one (61) index whose HIV-1 plasma viral load (HIV-1 RNA) was categorized at baseline: $<1000$ to $\geq 1,000,000$ copies/ml, showed a significant association between baseline HIV-1 plasma viral load, heterosexual HIV transmission ( $\mathrm{p}=0.059$ ) and STIs/RTIs ( $\mathrm{p}=0.057)$. Again, inheriting the HLA susceptible allele $\mathrm{C} * 07: 02, \mathrm{~B} * 07: 02$ and A*23:01 with increased plasma viral load, presence of untreated STIs, non-use of condom has been established from previous studies, to expose the sexual partners to high risk of HIV acquisition $^{22}$.

In this study, a total of $208(p=0.05)$ microorganisms were isolated from HIV positive individuals compared to 55 isolated from HIV negative individuals. Candida spp. 56 (26.9\%) was the most prevalent isolated from HIV positive individuals followed by Staphylococcus aureus and Escherichia coli $46(22.1 \%)$ respectively. This result is consistent with a study done among people living with HIV/AIDs in Port Harcourt ${ }^{41}$. In this report, Staphylococcus aureus had the highest percentage of occurrence 49 (29.7\%), followed by Escherichia coli 47 (28.5\%), Pseudomonas aeruginosa 46 (27.9\%) and Klebsiella pneumoniae 23 (13.9\%). Most of these organisms especially Candida spp. (26.9\%) and Gardnerella vaginalis (18.2\%) were opportunistic infections occurring in immunocompromised women. Immunocompromised HIV-1 
infected women are known to have increased rates of vaginal candidiasis with increased severity of pelvic inflammatory diseases.

This result is also consistent with another study done on lower genital tract infections in HIVseropositive women in India 9 . The laboratory findings showed high prevalence of BV (30\%), mixed infection (30\%), and candidiasis (10\%) among HIV-seropositive women $(p<0.001)$. But contrasts with other findings in the State of São Paulo ${ }^{42}$. In their study, they reported that Pseudomonas aeruginosa was the most frequently isolated microorganism, followed by Klebsiella pneumoniae in AIDs patients. In this study however, Escherichia coli and Staphylococcus aureus $(22.1 \%)$ respectively were the most frequently isolated microorganism followed by Klebsiella spp. 12(5.7\%) while Pseudomonas spp. was the least frequent $1(0.4 \%)$. Again, Candida spp. and Gardnerella vaginalis co-infected mostly with Klebsiella spp. (6/2 times) consecutively.

Out of the bacterial isolates that exhibited multidrug resistance, Staphylococcus aureus and Escherichia coli isolated from HIV positive individuals showed more resistance to Ceftazidime, (81.4\%) Gentamycin $(72.3 \%)$ and Tetracycline $(85.9 \%)$. This result is comparable to a recent study that reported that Staphylococcus aureus isolated from HIV positive individuals recorded the highest number of multidrug resistant bacteria $36(32.4 \%)^{41}$. The high levels of multidrug resistance in HIV seropositive individuals are a serious public Health concern in low income countries. This is because there is a lot of across- the counter purchase of antibiotics without doctor's prescription or laboratory test results. Result from the questionnaire shows that $70 \%$ of the clients who had itching, painful urination, vaginal and urethral discharge have had selfmedication of antibiotics mostly of substandard quality and only reports to the hospital when 
medRxiv preprint doi: https://doi.org/10.1101/2021.08.23.21262283; this version posted August 25, 2021. The copyright holder for this preprint (which was not certified by peer review) is the author/funder, who has granted medRxiv a license to display the preprint in perpetuity.

It is made available under a CC-BY-NC-ND 4.0 International license .

they cannot manage the situation. This is due to ignorance, poverty, poor hygiene practices as well as inconsistent use of condom.

From previous studies, different HLA class I alleles have been significantly associated with different rates of HIV diseases progression to AIDS while some haplotypes have been responsible for HIV-1 viral control during the last stage of HIV infection ${ }^{9}$. The HLA class I profile of Long-term Non-Progressors (LTNP) among the index (HIV positive subjects) were reviewed along baseline CD4+ count and plasma viral load (HIV-1 RNA). This was aimed to identify and match those alleles that have been described in other HLA studies in other African, African American countries as being independently associated with HIV disease protection, susceptibility and or alleles influencing seroconversion. In this study, it was observed that this group of indexes have HLA class I genes associated with low plasma viral loads (HIV-1 RNA) and high CD4+counts (highest/lowest CD4+ counts were 920/402cells/mm3 while the highest/lowest pVL were 181/20 copies/ml). Twenty-four, $24(8.51 \%)$ out of 282(54.02\%) were LTNPs. However, $80 \%(\mathrm{P}=0.05)$ of the partners of LTNP were HIV negative while $20 \%$ were HIV Positive. HIV-1 plasma viral loads can independently or in association with different HLA allele allotypes may contribute to HIV-1 transmission among Index-donor and Partner-recipient pairs. A study reported that any reduction in the plasma HIV-1 RNA is an important target for HIV prevention ${ }^{15}$. Another study of heterosexual Uganda HIV serodiscordant couples showed an association between the risk of HIV acquisition and donor plasma viral load (pVL). In their report, there was no HIV transmission observed when the pVL was below the threshold of 1,500 copies HIV-1 RNA/ml ${ }^{43}$ which is consistent with the $80 \%$, in this study whose partners were HIV-1 seronegative. However, we identified $20 \%$ of the partners of the index to be HIV-1 
medRxiv preprint doi: https://doi.org/10.1101/2021.08.23.21262283; this version posted August 25, 2021. The copyright holder for this preprint (which was not certified by peer review) is the author/funder, who has granted medRxiv a license to display the preprint in perpetuity.

It is made available under a CC-BY-NC-ND 4.0 International license .

seropositive though the index highest $\mathrm{pVL}$ recorded was $181 \mathrm{copies} / \mathrm{ml}$. However, this result is consistent with a recent study $^{44}$ who estimated the risk of HIV-1 acquisition in a sole sexual exposure estimated to be very low if the host viral load is low. It is well understood that one of the significant factors that affects the heterosexual transmission of HIV-1 in serodiscordant couples is the exposing dose of the virus in the plasma of the index. However, further studies may be able to identify why $20 \%$ of the partners of the index were seropositive when the highest pVL was below 200copies/ml.

In this study also, 3(12.5\%) of LTNPs inherited HLA B*57:01(12.9\%) and B*57:03 (4.6\%) which are haplotypes known to be responsible for HIV-1 viral control during the last stage of infection from previous studies ${ }^{9}$. HLA-B* 57:03 (4.6\%) was also documented to be responsible for slowing CD4+ decline. The beneficial HLA alleles *A1 (4.16\%), C*07:01(29.1\%) and $\mathrm{C}^{*} 06: 02(12.5 \%)$ were identified as alleles independently associated with protection from seroconversion. However, $\mathrm{B} * 07: 02 / \mathrm{C}^{*} 07: 02$ (33.3\%) and $\mathrm{C}^{*} 23: 01(4.16 \%)$ which was shown in previous studies $^{22}$ to be independently associated with seroconversion to HIV diseases was also identified within the cohort of LTNPs. It is therefore suggested that the LTNPs in this cohort may be carriers of non-virulent type of HIV or that their HLA generates an immunodominant response to an epitope in the Gag protein 24 and dynamic CD8+ responses which is critical for long- term control of HIV replication in these individuals. However, any escape from this response may lead to significant HIV seroconversion, increased viral loads and reduced CD4+ counts. Another study reported that HLA alleles that is defending the immune system have a true preference for the p24 Gag protein and CTL responses against Gag which moderately reduces HIV disease evolution ${ }^{16}$. Twelve percent $(12 \%)$ of the LTNPs in this study have known their 
HIV status over 7 years while 58\% have known their HIV-1 status between 0-12 months. Another study reported that 11 of the 13 LTNP (85\%) had a gene encoding HLA- B*57:01 variant which has been implicated to slow HIV disease evolution ${ }^{45}$. This study observed that LTNPs have HLA-B*57:01/*5703(17.5\%) and other documented common alleles. Again, LTNPs HLA-C alleles may be implicated with increased surface expression which is associated with reduced viral load and improved $\mathrm{CD}^{+} \mathrm{T}$ cell counts. This High HLA-C expression have improved HIV control through active cytotoxic $\mathrm{CD}^{+} \mathrm{T}$ cell responses as recorded in the Nigerians, African, European Americans ${ }^{46,47}$. 


\section{Conclusion}

Microorganisms isolated from the index were associated with high viral loads leading to low immunity and so are independent makers to HIV-1 transmission among serodiscordant couples. There is need to intensify health education to create public awareness on the use of low standard antibiotics purchased across the counter and self- medication. This will reduce multi drug resistance and prevent reemergence of opportunistic infections in the index. HLA class I alleles identified among LTNPs were similar to those significantly associated with resistance and susceptible to HIV-1 disease. 


\section{Acknowledgement}

I deeply appreciate HIV Research Trust Scholarship UK 2012 (HIVRT12-082) for sponsoring the preliminary training I required for this project which included, traveling to Project San Francisco (PSF) Kigali, Rwanda and Zambia Emory HIV Research Project (ZEHRP) Lusaka to get trained on Couples HIV Voluntary Counselling and testing, white cell pellet harvesting, DNA extraction and PCR. This was done under the supervision of Prof Susan Allen. I am grateful to Dr. Ma Lou. Associate Professor, University of Manitoba, HIV Host Genetics, National Microbiology Laboratories Winnipeg Canada for the provision of reagent and equipment used for the HLA studies as well as the analysis. My warm appreciation goes to Prof. Babatunde Salako, the Director General of the Nigerian Institute of Medical Research, who approved my Pre-Doctoral Research Development Grant through its' Graduate Initiative Programme (GIP) NIMR which was used for the completion of this study. 
medRxiv preprint doi: https://doi.org/10.1101/2021.08.23.21262283; this version posted August 25, 2021. The copyright holder for this preprint (which was not certified by peer review) is the author/funder, who has granted medRxiv a license to display the preprint in perpetuity.

It is made available under a CC-BY-NC-ND 4.0 International license.

\section{Duality of interest}

The authors have declared no duality of interests 
medRxiv preprint doi: https://doi.org/10.1101/2021.08.23.21262283; this version posted August 25, 2021. The copyright holder for this preprint (which was not certified by peer review) is the author/funder, who has granted medRxiv a license to display the preprint in perpetuity.

It is made available under a CC-BY-NC-ND 4.0 International license .

\section{References}

1. Kaiser, H.J. The Global HIV/AIDS Epidemic Global Health Policy www.kff.org >Global Health Policy 2017; 1-20

2. TREND OF NEW HIV INFECTIONS (2017). UNAIDS.WWW.unaids.org >countries > nigeria.

3. Webby (2011). AIDS and HIV Prevalence in Nigeria. Nigeria News. onlinenigeria.com https://onlinenigeria.com/articles/news/3360-aids-in-nigeria.html

4. Kharsany ABM and Karim QA. HIV Infection and AIDS in Sub-Saharan Africa: Current Status, Challenges and Opportunities. Open AIDS Journal 2016; 10: 34-48.

5. Allen S, Karita E, Chomba E, Roth D, Telfair J, Zulu I, Clark L._Promotion of couples' voluntary counselling and testing for HIV through influential networks in two African capital cities. BMC Public Health 2007; 7: 349

6. Bagala A (2006). Married Couples Top HIV Infection Rates. The Daily Monitor. Kampala https://allafrica.com/stories/200612041050.html

7. Afe AJ, Fadero T, Oluokun O. HIV Serodiscordant Couples in Southwest Nigeria: Prevalence and Associated Risk Factors. Journal of AIDS and HIV Infections 2015; 11: 103-108

8. Otuonye NM, Enabulele OI, Aluyi HS and Onwuamah CK. Sexual Transmitted Infections and HIV in Female Commercial Sex Workers in Lagos Nigeria. Nigerian Women Nigerian Journal of Clinical and Biomedical Research 2011; 5:22-30.

9. Goel V, Bhalla P, Sharma A and Mala YM. Lower genital tract infections in HIV-seropositive women in India. Indian Journal Sexually Transmitted Disease 2011; 32:103-107.

10. Archana S, Marfatia YS and Megha M. Reproductive tract infections in HIV positive women: A case control study. Indian Journal of Sexual Transmitted Diseases 2009; 30:16 18

11. Jin F, Jansson J, Law M, Prestage GP, Zablotska I and Imrie JC. Per-contact probability of HIV transmission in homosexual men in Sydney in the era of HAART. AIDS 2010; 24:907-913

12. Tan DH, Murphy K, Shah P, and Walmsley SL. Herpes simplex virus type 2 and HIV disease progression: a systematic review of observational studies. Journal of Infectious diseases 2013; 13: 502

13. Kesler MA, Kaul R, Liu J, Loutfy M, Gesink D, Myers T, and Remis RS (2015). Actual sexual risk and perceived risk of HIV acquisition among HIV-negative men who have sex with men in Toronto Canada. BioMed Central 2015; 16: 254-260. 
medRxiv preprint doi: https://doi.org/10.1101/2021.08.23.21262283; this version posted August 25, 2021. The copyright holder for this preprint (which was not certified by peer review) is the author/funder, who has granted medRxiv a license to display the preprint in perpetuity. It is made available under a CC-BY-NC-ND 4.0 International license .

14. AIDS Information. Guidelines for the use of Antiretroviral Agents in HIV-1-Infected Adults and Adolescents. Plasma HIV-1 RNA (Viral Load) and CD4 Count Monitoring. Available from https://aidsinfo.nih.gov/.../1/.../plasma-hiv-1-rna--viral-load--and-cd4-co. 2014

15. Brenner BG, Roger $M$ and Routy JP. Risk of HIV transmission in discordant partners. Journal of HIV Therapy 2007; 12: 19-21.

16. Tang J, Costello C, Keet IPM, Rivers C, Leblanc S, Karita E, Allen S, and Kaslow RA (2004). HLA class I homozygosity accelerates disease progression in human immunodeficiency virus type 1 infection. AIDS Research and Human Retroviruses 2004; 15 4-16.

17. Luo M. HLA class I associations with rates of HIV-1 seroconversion and disease progression in the Pumwani Sex Worker Cohort. Tissue Antigens 2015; 81: 93-107.

18. Yindom LM, Leligdowicz IA, Martin MP, Gao X, Qi Y, Zaman SM, Aveika A, Worwui A, Diatta M and Vincent T (2010). Influence of HLA Class I and HLA-KIR Compound Genotypes on HIV-2 Infection and Markers of Disease Progression in a Manjako Community in West Africa. Journal of Virology 2010; 84: 8202-8208.

19. Teixeira SL, de Sa NB, Campos DP, Coelho AB, Guimarães ML. Association of the HLAB*52 allele with non-progression to AIDS in Brazilian HIV-1-infected individuals. Gene Immunology 2014; 15: 256-262.

20. Blalsubramannian M, Pandhare J and Das C Immune Control of HIV. Journal of Life Science 2019; 1: 4-37.

21.Chen H, Ndhlouv ZM, Liu D, Porter LC, Fang J, Brockman MA, Miura T, Darko S, BrummeZL. T-cell receptor clonotypes modulates the protective effect of HLA class I alleles in HIV -1 infection. Nature Immunology 2012; 10: 691-700.

22.Peterson TA, Kimani CJ, Wachihi T, Bielawny T, Mendoza L, Thavaneswaran S, Narayansingh MJ, Kariri T, Liang B, Ball TB, Ngugi EN, Plummer FA and Luo M. HLA class 1 association with rates of HIV-1 seroconversion and diseases progression in the Pumwani Sex Workers Cohort. Tissue Antigen 2013; 81: 93-107

23. Oyeka CA. An Introduction to applied Statistical Methods in the Sciences. Nobern Publishing Company Enugu. 3rd edition. 1992; 436pp.

24. NACA/AVAC. NACA launches demonstration on HIV/AID prevention in serodiscordant couples Available from, www.nigeriannewspapers.today/2015/09/10/naca-launches 2015 
25. Iwatram-Negrón T, and El-Bassel N. Systematic Review of Couple-Based HIV Intervention and Prevention Studies: Advantages, Gaps, and Future Directions. AIDS and Behavior 2014; 18: 1864-1887.

26. Cheesbrough M. Medical Laboratory Manual for Tropical Countries (11). Cambridge university press. Cambridge UK. 2010; 433pp.

27. Hainer BL and Gibson MV. Vaginitis: Diagnosis and Treatment. American Family Physician 2011; 83: 807-815.

28. Barry AL, Amsterdam D, Coyle MB, Gerlach EH, Thornsberry C and Hawkinson RH. (1979) Simple inoculum standardizing system for antimicrobial disk susceptibility tests. J Clin Microbiol. 10(6):910-8.

29. Giordano M, Kelleher T, Colonno RJ, Lazzarin A and Squires $K$. The effects of the Roche AMPLICOR HIV-1 MONITOR ${ }^{\circledR}$ UltraSensitive Test versions 1.0 and 1.5 viral load assays and plasma collection tube type on determination of response to antiretroviral therapy and the inappropriateness of cross-study comparisons. Journal of Clinical Virology 2006; 35: $420-442$

30. Burkhard G. Precise Cell Numeration and CD4/CD8 Counting in HIV/AIDS. PARTEC CYFLOW for CD4 AND CD8 Count. Institute of Radiobiology, University Hospital Münster 2004: 10pp.

31. Qiagen ${ }^{\circledR}$ Aamp® DNA Mini and Blood Mini Handbook. www.qiagen.co._2013;28pp

32. Shampo MA, Kyle RA and Kary BM. Nobel Laureate for procedure to replicate DNA Proceedings. Mayo Clinic 2002; 77: 606-612.

33. Roth J. Agarose Gel Electrophoresis Protocols. Agarose Gels for Single Stranded DNA Protocol on-line. www.protocolonline.org/.../Agarose_Gel_Electrophoresis/index.html 2004

34. Bronner FI, Quali MA, Tumer DJ and Swerdlow H. Improved Protocols for Iiiumia Sequencing. Curr Protoc Hum Genetics 2009; 62 :1 18-27.

35. Sanger FN, and Coulson A. DNA sequencing with chain-terminating inhibitors.

Proceedings of the National Academy of Sciences of United States of America 1977; 74: 54635467

36. Douek DC, Roederer M and Koup RA. "Emerging Concepts in the Immunopathogenesis of AIDS". Annual Review of Medicine 2009; 60:471-484. 
37. Applied Biosystems. DNA Sequencing by Capillary Electrophoresis Chemistry Guide: (Second Edition), Applied Biosystems, Foster City, California 2009; 450pp.

38. CodonExpress TM. CodonExpress Genotyping Software Manual: Genotyping Based on Taxonomy-based Sequence Analysis (TBSA) to resolve HLA heterozygous combinations. University of Manitoba, Canada 2010; 20pp.

39. Sequencher version 5 DNA Analyser. Available from Gene Codes Corporation www.gnecodes.com 2011

40. Ogbeibu AE. Biostatistics. A Practical Approach to Research and Data Handling. Mindex Publishing Co. Ltd. Benin city 2005; 264pp.

41. Kemajou TS, Ajugwo AO, Oshoma CE, and Enabulele OI. Antibiotic Resistance of Bacterial Isolates from HIV Positive Patients with Urinary Tract Infection (UTI) in Portharcourt, Nigeria. Journal of AIDS and Clinical Research 2016; 7:8

42. Lopes RE, Canini S, Reinato L and Gir E. Prevalência de bactérias gram-negativas em portadores de HIV internados em serviço especializado. Acta Paulista de Enfermagem 2015; 28:281-282

43. Fox J and Fidler S (2010). Sexual Transmission of HIV-1. Journal of Antiviral Research 2010; 88:1276-285.

44. Kesler MA, Kaul R, Liu J, Loutfy M, Gesink D, Myers T, and Remis RS. Actual sexual risk and perceived risk of HIV acquisition among HIV-negative men who have sex with men in Toronto Canada. BioMed Central 2015; 16 254-260

45. Davis DM (2014). The Compatibility Gene (ebook). How Our Bodies Fight Disease, Attract Others, and Define Our Selves. Available from, www.worldcat.org/title/compatibility-gene-howour-bodies-fight. Oxford University UP 2014; 4 5- 24.

46. Zipeto D and Beretta A (2012). HLA-C Friends or Foes? Retrovirology 939

47. Apps R, Qi Y, Carlson JM, Chen H, Gao X, Thomas R (2013). Influence of HLA-C Expression Level on HIV Control. Science 2013; 340: 87-91 
medRxiv preprint doi: https://doi.org/10.1101/2021.08.23.21262283; this version posted August 25, 2021. The copyright holder for this preprint (which was not certified by peer review) is the author/funder, who has granted medRxiv a license to display the preprint in perpetuity.

It is made available under a CC-BY-NC-ND 4.0 International license
. 
Table 1: Sociodemographic Characteristics of Study Participant

$(n=542)$

\begin{tabular}{|c|c|c|c|c|c|c|c|c|}
\hline \multirow[b]{2}{*}{ Age group } & \multicolumn{3}{|c|}{ Concordant HIV Positive Couples } & \multicolumn{2}{|c|}{ Concordant HIV Negative Couples } & \multicolumn{3}{|c|}{ Serodiscordant Couples } \\
\hline & & Total No - 52 & Frequency $(\%)$ & Total No -42 F & $\mathbf{y}(\%)$ & Total No - 448 & Frequency $(\%)$ & Total \\
\hline $20-25$ & & 2 & $(0.3)$ & 0 & $(0.0)$ & 7 & $(1.3)$ & \\
\hline $31-35$ & & 10 & (1.9) & 6 & $(1.1)$ & 114 & $(21.0)$ & \\
\hline $36-40$ & & 14 & (2.6) & 10 & (1.9) & 118 & $(21.9)$ & \\
\hline $41-45$ & & 12 & $(2.2)$ & 12 & $(2.2)$ & 76 & $(14.0)$ & \\
\hline Total & & $52(26)$ & (9.5) & $42(21)$ & (7.8) & $448(224)$ & $(82.7)$ & 542 \\
\hline
\end{tabular}


Table 2: Impact of Baseline HIV-1 RNA (Viral load) and Other Risk Factors in HIV-1 Transmission in the Index $\mathrm{n}=69$

\begin{tabular}{llccccccc}
\hline \multicolumn{2}{c}{ Baseline HIV-1 RNA in copies/ml } & & & & & \\
\multicolumn{1}{c}{ Categories } & No & Frequency & MCU & FCU & Vaginal & Oral & Anal & STI/RTI \\
\hline$<1000$ & 16 & $(23.2)$ & 10 & 0 & 42 & 13 & 0 & 2 \\
$1000-10,000$ & 9 & $(13.0)$ & 5 & 0 & 2 & 1 & 1 & 7 \\
$10,01-100,000$ & 42 & $(60.9)$ & 26 & 3 & 8 & 3 & 4 & 32 \\
$>1,000000$ & 2 & $(2.9)$ & 1 & 0 & 0 & 0 & 0 & 3 \\
& & & & & & & & \\
Total & 69 & & 42 & 3 & 52 & 17 & 5 & 47 \\
P-value & & & .924 & 1.000 & 0.057 & .752 & 1.000 & 0.059 \\
\hline
\end{tabular}

Low viral load is $40-500$ copies $/ \mathrm{ml}$.

High viral load -5,000-10,000 copies/ml

Vaginal sex, Oral sex and Anal sex

STI/RTI -Sexual Transmitted Infection and Reproductive Tract Infection

MCU -Male Condon use FCU-Female condom use

NA-Not using MC\& FC

Baseline viral load was restricted to Index whose risk factors were positive 
medRxiv preprint doi: https://doi.org/10.1101/2021.08.23.21262283; this version posted August 25, 2021. The copyright holder for this preprint (which was not certified by peer review) is the author/funder, who has granted medRxiv a license to display the preprint in perpetuity.

It is made available under a CC-BY-NC-ND 4.0 International license .

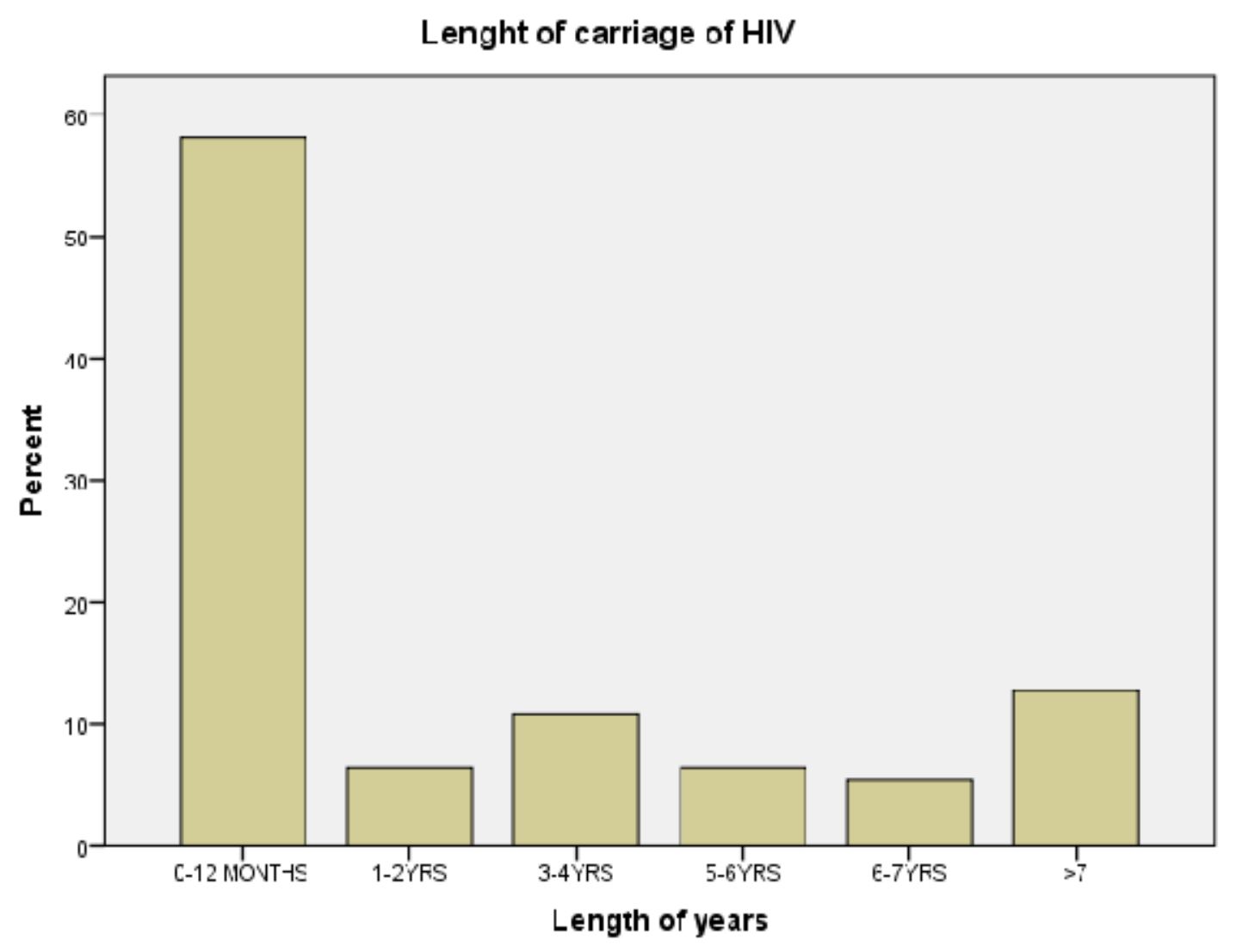

Figure 1: Length of Carriage of HIV in Long-term Non -Progressor's (LTNP) 
Table 3: Profile of HLA-Class I Alleles CD4+ CD8+ and pVL of Long-term of Non -Progressor's (LTNP) among HIV Positive Individuals

\begin{tabular}{|c|c|c|c|c|c|c|}
\hline Sex & HLA- A & 11/A2 & HLA -B1/B2 & HLA -C1/C2 & CD4 cells/mm3 & pvL copies/ml \\
\hline $\mathbf{F}$ & $\mathbf{A} * 02$ & $* 34$ & $B * 5102 * 5535$ & $C * 0401 * 1601$ & 696 & 20 \\
\hline $\mathbf{M}$ & A*03 & *32 & B*1801 *4501 & $C * 0205 * 1607$ & 680 & 200 \\
\hline $\mathbf{M}$ & $A * 3002$ & $2 * 8001$ & $B * 1826 * 1807$ & $C * 0202 * 0701$ & 711 & 20 \\
\hline $\mathbf{F}$ & $A * 2301$ & *6802 & B*5301 *5301 & $\mathrm{C} * \mathbf{B S}$ & 879 & 200 \\
\hline $\mathbf{M}$ & $A * 2902$ & $* 3001$ & $B * 5703 * 1510$ & $C * 0401 * 1601$ & 586 & 181 \\
\hline $\mathbf{F}$ & $A * 3002$ & *3303 & $B * 5301 * 5301$ & $\mathrm{C} * 0401 * 0701$ & 850 & 42 \\
\hline $\mathbf{F}$ & $\mathbf{A} * \mathbf{B S}$ & & $B * 3520 * 3501$ & $\mathrm{C} * 0401 * 0701$ & 927 & 141 \\
\hline $\mathbf{F}$ & $\mathbf{A} * 03$ & $* 29$ & $B * 0702 * 5701$ & $C * 06 * 15$ & 624 & 20 \\
\hline $\mathbf{F}$ & $\mathbf{A} * \mathbf{3 0}$ & $* 30$ & $B * 0801 * 1510$ & $C * 0401 * 1701$ & 570 & 20 \\
\hline $\mathbf{F}$ & A*01 & $* 68$ & $B * 1518 * 3501$ & $\mathrm{C} * 0401 * 0302$ & 967 & 20 \\
\hline $\mathbf{F}$ & A*02 & $* 74$ & $B * 0820 * 0805$ & C*0701 *0702 & 841 & 20 \\
\hline $\mathbf{F}$ & $A * 23$ & $* 68$ & $B * 1510 * 5801$ & $\mathrm{C} * 0304 * 0602$ & 733 & 20 \\
\hline
\end{tabular}


Page 2 of table 3

\begin{tabular}{|c|c|c|c|c|c|c|}
\hline $\mathbf{F}$ & A*0201 & $* 2402$ & $B * 4496 * 5301$ & $C * 04001 * 0401$ & 538 & 20 \\
\hline $\mathbf{M}$ & $A * 3001$ & $* 6602$ & B*0762 *5801 & C*0701 *0702 & 495 & 20 \\
\hline $\mathbf{F}$ & A*0201 & *0301 & $B * 07 * 51$ & C*0702 *1601 & 812 & 92 \\
\hline $\mathbf{F}$ & $A * 0202$ & *3301 & B*5701 *5801 & C*0401 *0601 & 561 & 20 \\
\hline $\mathbf{M}$ & $A * 0701$ & $* 1701$ & $B * 0702 * 4201$ & $\mathrm{C} * 03 \quad * 68$ & 622 & 20 \\
\hline $\mathbf{M}$ & $A * 0202$ & *3001 & $B * 4418 * 5305$ & $\mathrm{C} * 0602 * 1601$ & 441 & 20 \\
\hline M & $A * 0201$ & *0202 & $B * 1503 * 3501$ & $\mathrm{C} * 0602 * 1203$ & 402 & 20 \\
\hline $\mathbf{F}$ & $A * 3001$ & *6801 & $B * 4901 * 5802$ & $\mathrm{C} * 0602 * 0602$ & 625 & 21 \\
\hline $\mathbf{F}$ & A*0301 & $* 3001$ & $B * 4403 * 4453$ & $\mathrm{C} * 04 * 17$ & 668 & 23 \\
\hline M & $\mathbf{A} * 02$ & $* 74$ & $B * 0702 * 5801$ & C*0701 *0702 & 619 & 41 \\
\hline $\mathbf{M}$ & $A * 3001$ & $* 3001$ & B $* 5301 * 5313$ & $\mathrm{C} * 0701 * 1801$ & 711 & 20 \\
\hline $\mathbf{F}$ & $\mathrm{A} * 6801$ & $* 6802$ & $B * 52 \quad * 67$ & $\mathrm{C} * 0401 * 0401$ & 920 & 20 \\
\hline
\end{tabular}

CD4+ is Baseline result

PLV Plasma Viral load (HIV-1-RNA) is baseline viral load result

Low viral load is $40-500$ copies $/ \mathrm{ml}$.

High viral load -5,000-10,000 copies/ml

A*BS - Bad sequence HLA-A allele

B*BS-- Bad sequence HLA-B allele

$\mathrm{C} * \mathrm{BS}$ Bad sequence HLA-C allele 
Table 4a. Aetiologic Agents Isolated and Occurrence of Mixed Infections in HIV Negative Individuals

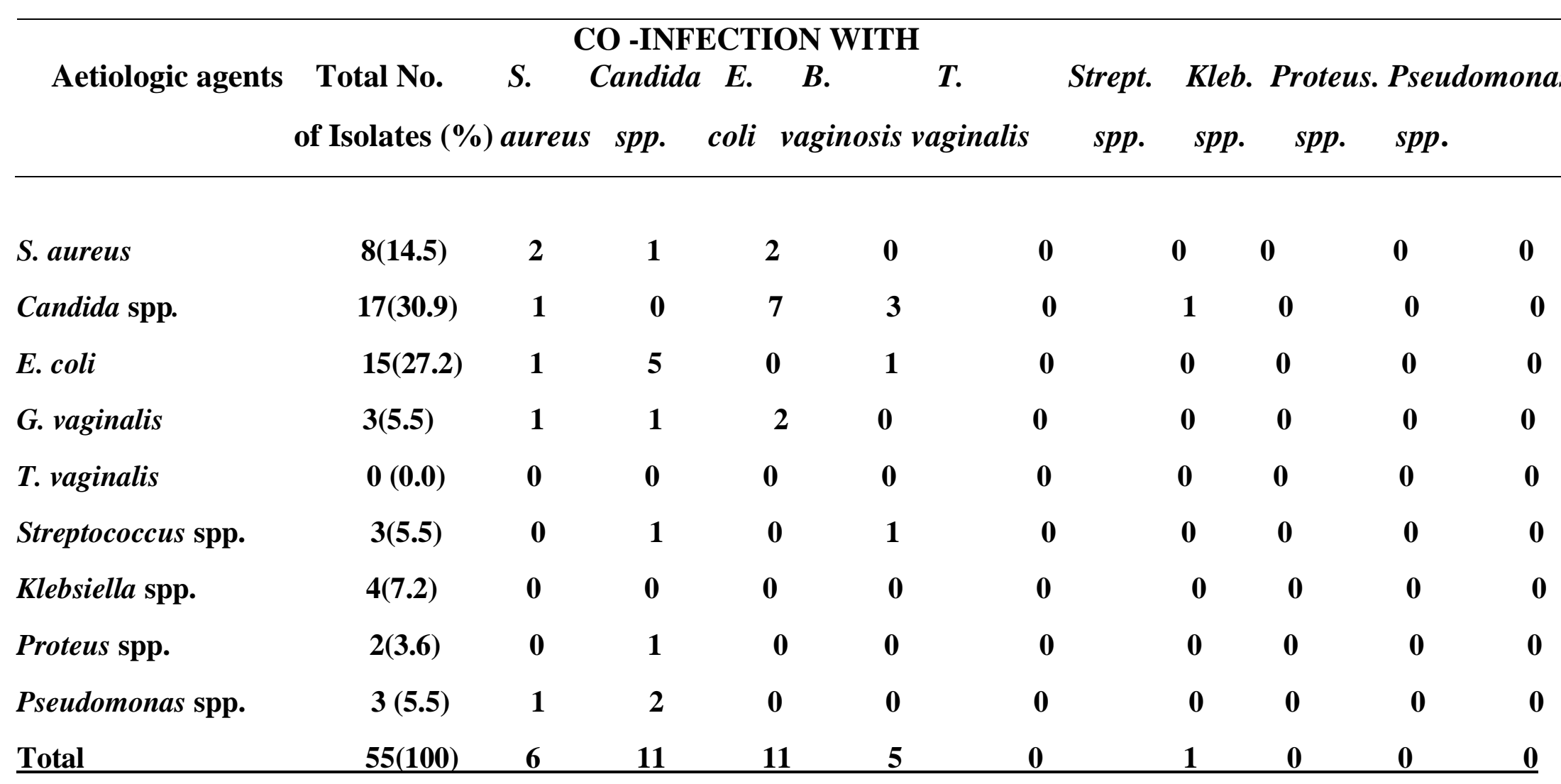

A total number of 55 aetiologic agents were isolated from HIV negative individuals. 
Table 4b: Aetiologic Agents Isolated and Occurrence of Mixed Infections in HIV Positive Individuals

\begin{tabular}{|c|c|c|c|c|c|c|c|c|c|c|}
\hline \multirow{3}{*}{$\begin{array}{r}\text { Aetiologic agents } \\
\text { o }\end{array}$} & \multirow{3}{*}{$\begin{array}{l}\text { Total No. } \\
\text { of Isolates (\%) }\end{array}$} & \multirow{3}{*}{$\begin{array}{l}\text { S. } \\
\text { aureus }\end{array}$} & \multirow{3}{*}{$\begin{array}{l}\text { Candida } \\
\text { spp. }\end{array}$} & \multirow{3}{*}{$\begin{array}{l}E . \\
\text { coli }\end{array}$} & \multicolumn{4}{|c|}{ CO -INFECTION WITH } & \multirow{2}{*}{\multicolumn{2}{|c|}{ Proteus. Pseudom }} \\
\hline & & & & & $\boldsymbol{B}$. & $T$ & Strept. & Klebsiella & & \\
\hline & & & & & vaginosis & vaginalis & spp. & spp. & spp. & spp. \\
\hline S. aureus & $46(22.1)$ & $\mathbf{0}$ & 3 & $\mathbf{1}$ & 4 & $\mathbf{0}$ & $\mathbf{0}$ & $\mathbf{0}$ & $\mathbf{0}$ & $\mathbf{0}$ \\
\hline Candida spp. & $56(26.9)$ & $\mathbf{0}$ & $\mathbf{0}$ & 1 & $\mathbf{0}$ & $\mathbf{0}$ & $\mathbf{0}$ & 2 & $\mathbf{0}$ & $\mathbf{0}$ \\
\hline E. coli & $46(22.1)$ & 1 & 3 & $\mathbf{0}$ & $\mathbf{0}$ & $\mathbf{0}$ & $\mathbf{0}$ & $\mathbf{0}$ & $\mathbf{0}$ & $\mathbf{0}$ \\
\hline G. vaginalis & $38(18.2)$ & $\mathbf{0}$ & 2 & $\mathbf{0}$ & $\mathbf{0}$ & $\mathbf{0}$ & $\mathbf{0}$ & $\mathbf{0}$ & $\mathbf{0}$ & $\mathbf{0}$ \\
\hline T. vaginalis & $3(1.4)$ & $\mathbf{0}$ & 2 & 1 & $\mathbf{0}$ & $\mathbf{0}$ & $\mathbf{0}$ & $\mathbf{0}$ & $\mathbf{0}$ & $\mathbf{0}$ \\
\hline Streptococcus spp. & $4(1.9)$ & 2 & 3 & $\mathbf{0}$ & 2 & 2 & $\mathbf{0}$ & $\mathbf{0}$ & $\mathbf{0}$ & $\mathbf{0}$ \\
\hline Klebsiella spp. & $12(5.7)$ & $\mathbf{0}$ & 6 & 2 & 2 & $\mathbf{0}$ & $\mathbf{0}$ & $\mathbf{0}$ & $\mathbf{0}$ & $\mathbf{0}$ \\
\hline Proteus spp. & $2(0.96)$ & $\mathbf{0}$ & 1 & $\mathbf{0}$ & 1 & $\mathbf{0}$ & $\mathbf{0}$ & $\mathbf{0}$ & $\mathbf{0}$ & $\mathbf{0}$ \\
\hline Pseudomonas spp. & $1(0.4)$ & $\mathbf{0}$ & $\mathbf{0}$ & $\mathbf{0}$ & $\mathbf{0}$ & $\mathbf{0}$ & $\mathbf{0}$ & $\mathbf{0}$ & $\mathbf{0}$ & $\mathbf{0}$ \\
\hline Total & $208(100)$ & 3 & 20 & 5 & 9 & 2 & 0 & 2 & 0 & $\mathbf{0}$ \\
\hline
\end{tabular}

A total of 208 aetiologic agents were isolated from HIV Positive individuals. 
Table 5a: Antibiotic Susceptibility Pattern of Microbial Agents Isolated from HIV Positive and Negative Individuals

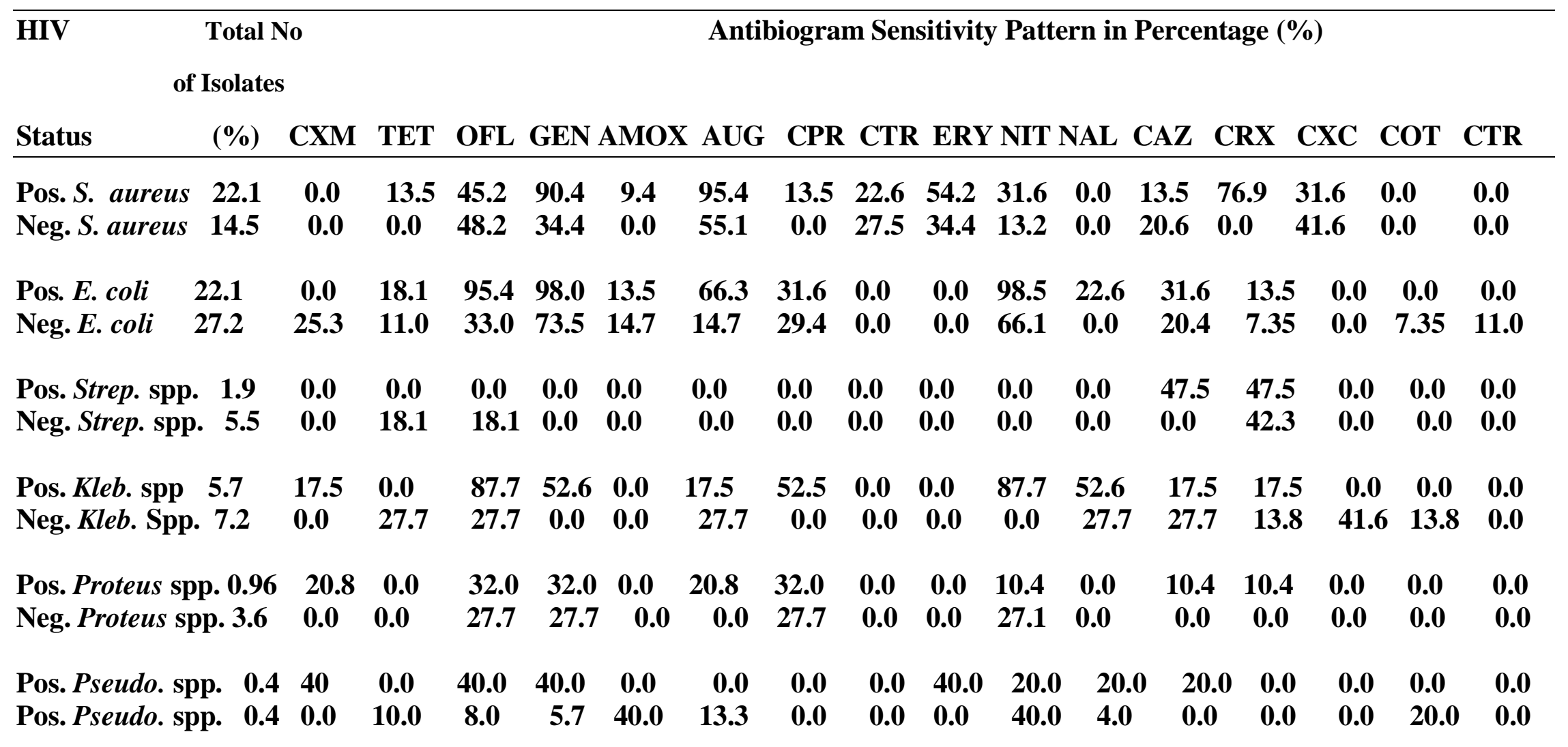

Pos. is HIV positive status, Neg. is HIV negative status.

0.0 - means the isolates showed no sensitivity to antibiogram 
Table 5b: Antibiotic Resistant Pattern of Aetiologic agents Isolated from HIV Positive and Negative Individuals

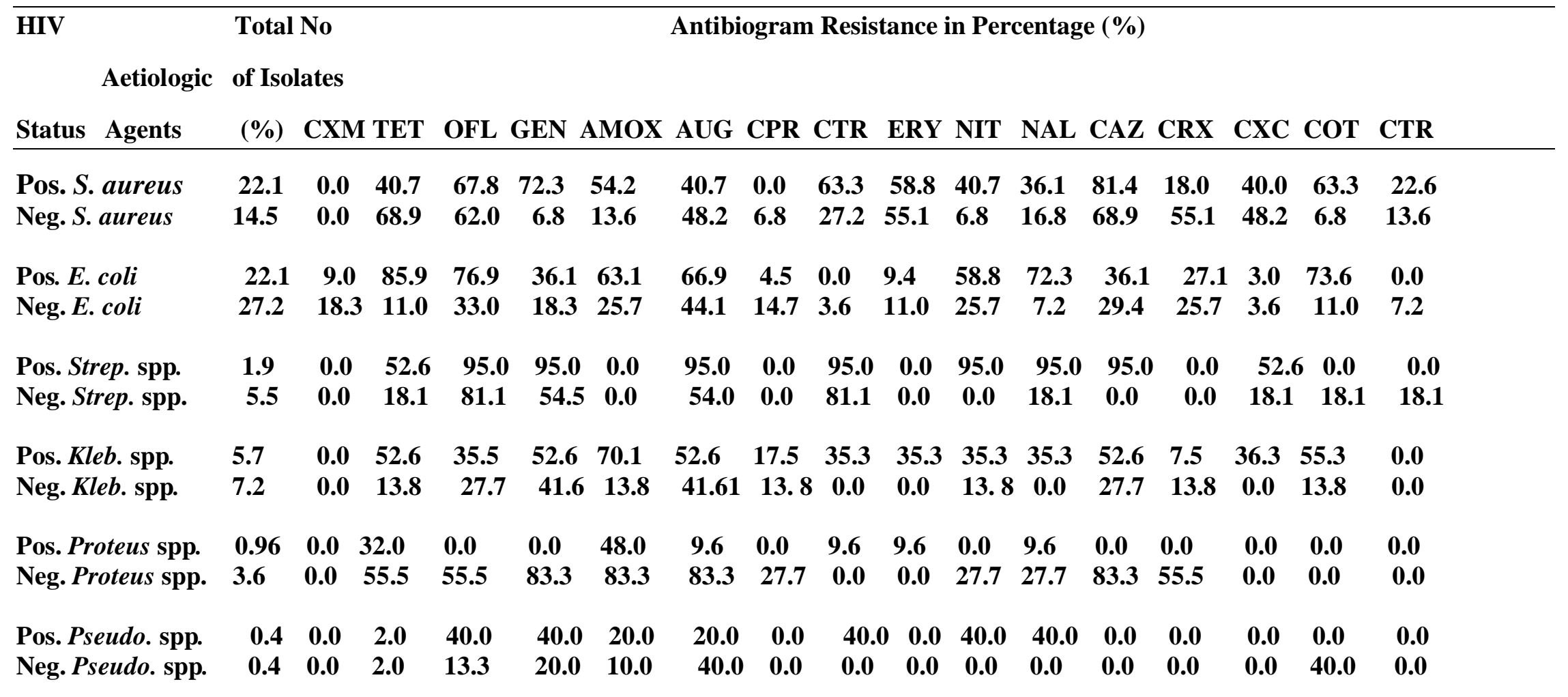

Pos. is HIV Positive status and Neg. is HIV negative status.
0.0 -
means
the
isolates
showed
no
resistance
to
antibiogram 
medRxiv preprint doi: https://doi.org/10.1101/2021.08.23.21262283; this version posted August 25, 2021. The copyright holder for this preprint (which was not certified by peer review) is the author/funder, who has granted medRxiv a license to display the preprint in perpetuity.

It is made available under a CC-BY-NC-ND 4.0 International license
. 